\title{
Protective effects of osthole against inflammation induced by lipopolysaccharide in BV2 cells
}

\author{
YUXIN BAO*, XIAOLIN MENG ${ }^{*}$, FANGNING LIU, FEI WANG, \\ JINHUI YANG, HAIYU WANG and GUANGHONG XIE
}

Department of Clinical Veterinary Medicine, College of Veterinary Medicine, Jilin University, Changchun, Jilin 130062, P.R. China

Received July 5, 2017; Accepted December 1, 2017

DOI: $10.3892 / \mathrm{mmr} .2018 .8447$

\begin{abstract}
Inflammation and oxidative stress are implicated in the development of neurodegenerative diseases. Osthole is a compound that is extracted from She Chuang $\mathrm{Zi}$, which is a type of traditional Chinese medicine. Osthole has previously been demonstrated to exhibit anticancer activities and has a low toxicity. However, to the best of our knowledge, the anti-inflammatory effects of osthole in microglial cells have not been investigated extensively. The aim of the present study was to investigate the potential protective effects of osthole against inflammation induced by lipopolysaccharide (LPS) in microglial cells. The present study employed LPS-stimulated BV2 mouse microglia to establish an inflammatory cell model and to investigate the anti-inflammatory effects of osthole. Cells were pretreated with osthole for $1 \mathrm{~h}$ prior to LPS $(10 \mu \mathrm{g} / \mathrm{ml})$ stimulation. At $6 \mathrm{~h}$ after the addition of LPS, alterations in the levels of inflammatory factors, including tumor necrosis factor (TNF)- $\alpha$, interleukin (IL)- 6 and IL-1 $\beta$, were determined by ELISA. Furthermore, at $24 \mathrm{~h}$ after the addition of LPS, western blot analysis was performed to analyze the alterations in the protein expression of nuclear factor $-\kappa \mathrm{B}(\mathrm{NF}-\kappa \mathrm{B}) \mathrm{p} 65$, phosphorylated-NF- $\kappa \mathrm{B}$ p 65, nuclear factor erythroid 2-related factor 2 (Nrf2) and heme oxygenase (HO)-1. The results demonstrated that the secretion of the inflammatory cytokines TNF- $\alpha$, IL- 6 and IL- $1 \beta$ by LPS-stimulated BV2 cells was significantly reduced by osthole treatment. Simultaneously, osthole treatment inhibited the LPS-induced activation of the $\mathrm{NF}-\kappa \mathrm{B}$ signaling pathway. In addition, osthole upregulated the expression of Nrf2 and HO-1 in a dose-dependent manner.
\end{abstract}

Correspondence to: Professor Guanghong Xie, Department of Clinical Veterinary Medicine, College of Veterinary Medicine, Jilin University, 5333 Xi'an Road, Changchun, Jilin 130062, P.R. China

E-mail: xiegh@jlu.edu.cn

*Contributed equally

Key words: anti-inflammatory, osthole, nuclear factor- $\kappa \mathrm{B}$ signaling pathway, nuclear factor erythroid 2-related factor 2 signaling pathway, oxidative stress
Based on these results, osthole may exhibit anti-inflammatory effects via the $\mathrm{NF}-\kappa \mathrm{B}$ and Nrf2 pathways, indicating that osthole has the potential to be developed into an effective anti-inflammatory drug.

\section{Introduction}

Osthole $\left(\mathrm{C}_{15} \mathrm{H}_{16} \mathrm{O}_{3}\right)$, or 7-methoxy-8-isopentenoxycoumarin, is also termed 'She Chuang $\mathrm{Zi} \mathrm{Su}$ ' in China. As a traditional Chinese medicine, it has been widely used in the treatment of various diseases. According to reports, osthole exerts numerous positive effects, including antioxidant (1), anti-hypertension (2), anti-arrhythmia (3), anticancer (4) and antitumor (5) activities. Lipopolysaccharide (LPS), which is also termed bacterial endotoxin (6), is an important component of the cell wall of Gram-negative bacterial cells. Previous studies have demonstrated that LPS induces inflammatory responses in cells (7-11). Therefore, the present study employed LPS to establish an inflammatory model for the investigation of the potential anti-inflammatory properties of osthole. Inflammation of the central nervous system may lead to the development of various diseases, including Alzheimer's disease, multiple sclerosis and Parkinson's disease (12). Nerve cells are fragile cell types and their regulatory ability is weak during inflammation and oxidative stress. However, research concerning nerve inflammation and their anti-inflammatory mechanisms is lacking.

Nuclear factor $-\kappa \mathrm{B}(\mathrm{NF}-\kappa \mathrm{B})$ is an early-stage nuclear transcription factor. It participates in the early stage of the immune response and in each stage of inflammation, as $\mathrm{NF}-\kappa \mathrm{B}$ regulates numerous factors that are associated with inflammation (13). At rest, a complex between $N F-\kappa B$ and $\mathrm{NF}-\kappa \mathrm{B}$ inhibitor (I $\kappa \mathrm{B})$ forms in the cytoplasm. If stimulated, $\mathrm{I} \kappa \mathrm{B}$ becomes activated, which frees $\mathrm{NF}-\kappa \mathrm{B}$ and allows $\mathrm{NF}-\kappa \mathrm{B}$ to transfer from the cytoplasm to the nucleus (14) to induce an inflammatory response in the body. It has been previously verified that the NF- $\kappa \mathrm{B}$ pathway is closely associated with numerous diseases. For example, Brambilla et al (15) demonstrated that spinal cord injuries may be treated with drugs that inhibit the NF- $\mathrm{B}$ pathway, while Noort et al (16) reported that the activation of $N F-\kappa B$ may be one cause of rheumatoid arthritis. Additionally, Duh et al (17) confirmed that human immunodeficiency virus type 1 , which causes the pathogenesis 
of acquired immune deficiency syndrome, is also associated with $N F-\kappa B$. These diseases are all associated with inflammation. Therefore, we hypothesized that the activation of the $\mathrm{NF}-\kappa \mathrm{B}$ signaling pathway may also be a major factor in the development of neurodegenerative disease.

Nuclear factor erythroid 2-related factor $2(\mathrm{Nrf} 2)$ is an antioxidant response element. In normal conditions, Nrf2 combines with kelch-like ECH-associated protein 1 (Keap-1), and this combined form of Nrf2 is degraded. Degradation effectively controls the level of Nrf2 in cells (18). Heme oxygenase-1 (HO-1) is located downstream of Nrf2 (19); therefore, alterations in the levels of Nrf2 subsequently affect the expression of HO-1. In the present study, we hypothesized that osthole may protect cells against inflammation through the Nrf2 and NF- $\kappa$ B pathways. The aim of the present study was to determine the potential protective effect of osthole against inflammation in cells and to investigate the underlying mechanisms.

\section{Materials and methods}

Reagents. Osthole (98\%) was purchased from Sigma-Aldrich (Merck KGaA, Darmstadt, Germany) and was dissolved in $0.1 \%$ dimethyl sulfoxide (DMSO) to reach a concentration of $0.7 \mathrm{mg} / \mathrm{ml}$ and stored at $-20^{\circ} \mathrm{C}$. The final concentration for DMSO used to dissolve the drug was $0.1 \%$; DMSO exhibited no effect on cell viability, as demonstrated in a previous study (20). Dulbecco's modified Eagle's medium (DMEM) was purchased from Hyclone (GE Healthcare Life Sciences, Logan, UT, USA). LPS was purchased from Sigma-Aldrich (Merck KGaA). The components of the cell lysis buffer were obtained from Beyotime Institute of Biotechnology (Haimen,

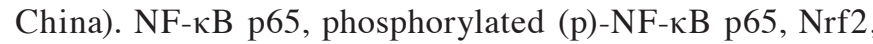
$\mathrm{HO}-1, \mathrm{I} \kappa \mathrm{B} \alpha, \mathrm{p}-\mathrm{I} \kappa \mathrm{B} \alpha$, lamin $\mathrm{B}$ and $\beta$-actin primary antibodies were obtained from Cell Signaling Technology, Inc. (Danvers, MA, USA). MTT reagent and DMSO were provided by Wuhan Boster Biological Technology, Co., Ltd. (Wuhan, China). Fetal bovine serum (FBS) was obtained from Zhejiang Tianhang Biotechnology Co., Ltd. (Huzhou, China). ELISA kits were purchased from Cell Signaling Technology, Inc.

Cell culture. BV2 mouse microglial cells were obtained from the Type Culture Collection of the Chinese Academy of Sciences (Shanghai, China) and cultured in DMEM with $10 \% \mathrm{FBS}$ and $1 \%$ antibiotics $(100 \mathrm{U} / \mathrm{ml}$ penicillin and streptomycin) (5). Cells were cultured at $37^{\circ} \mathrm{C}$ in a humidified atmosphere of $5 \% \mathrm{CO}_{2}$. The medium was changed once a day and passage occurred when the cells grew on a logarithmic scale.

Cell viability assay. BV2 cells in the logarithmic growth phase were added to 96 -well plates $\left(7 \times 10^{3}\right.$ cells/well) and cultured in a cell culture box at $37^{\circ} \mathrm{C}$ for $12 \mathrm{~h}$ until the cells completely attached to the wall. At $1 \mathrm{~h}$ prior to LPS $(1 \mu \mathrm{g} / \mathrm{ml})$ stimulation, different concentrations of osthole $(4,7$ and $10 \mu \mathrm{g} / \mathrm{ml})$ were added to each well at $37^{\circ} \mathrm{C}$, and the activity of cells was detected at $24 \mathrm{~h}$ after stimulation with LPS. For the control group, an equivalent volume of empty media was added. MTT reagent was added to all cell groups and were subsequently cultivated in the incubator for $2-4 \mathrm{~h}$ at $37^{\circ} \mathrm{C}$, leading to the development of purple crystals. DMSO (150 $\mu \mathrm{l} /$ well) was added and shaken until all of the crystals disappeared. The optical density of the 96-well plate was measured at $570 \mathrm{~nm}$.

Western blotting. BV2 cells were stimulated with LPS $(1 \mu \mathrm{g} / \mathrm{ml})$ at $1 \mathrm{~h}$ after treatment with osthole $(4,7$ and $10 \mu \mathrm{g} / \mathrm{ml})$ in 6 -well plates $\left(1 \times 10^{6}\right.$ cells/well), and total protein samples were collected at $24 \mathrm{~h}$ after the addition of LPS. Protein extraction was performed in strict accordance with the specifications of the Protein Extraction kit (cat. no. AR0103; Boster Biological Technology, Pleasanton, CA, USA). Following removal of the medium, the cells were washed with $4^{\circ} \mathrm{C}$ pre-cooled PBS three times. Subsequently, $1 \mathrm{ml}$ lysate was added, including $10 \mu \mathrm{l}$ protease inhibitors and $10 \mu \mathrm{l}$ phosphorylase inhibitors. After $30 \mathrm{~min}$, cells from the 6-well plates were scraped, collected in a $1.5-\mathrm{ml}$ centrifuge tube and centrifuged for $5 \mathrm{~min}$ at $4^{\circ} \mathrm{C}$ and $1,000 \mathrm{x}$. The supernatant obtained following centrifugation was the protein, and the protein concentration was detected with a BCA protein assay kit. The protein (15 $\mu \mathrm{g} / \mathrm{lane})$ was concentrated in $10 \%$ of the concentrated gel at $80 \mathrm{~V}$ for $30 \mathrm{~min}$ and separated by $12 \%$ SDS-PAGE at $120 \mathrm{~V}$ for $70 \mathrm{~min}$. After cutting the gel, the target protein was transferred to polyvinylidene difluoride membranes. Membranes were subsequently incubated with $5 \%$ bovine serum albumin for $2 \mathrm{~h}$, followed by incubation with primary antibodies, including NF- $\mathrm{B}$ p65,

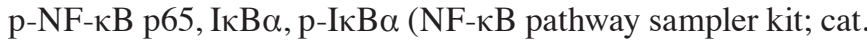
no. 9936), Nrf2 (cat. no. 12721), HO-1 (cat. no. 5853), lamin B (cat. no. 12255) and $\beta$-actin (cat. no. 3700) overnight at $4^{\circ} \mathrm{C}$. All antibodies were purchased from CST Biological Reagents Co., Ltd. (Shanghai, China) and were added at 1:1,000 dilution. Prior to incubation with secondary antibodies, the membrane was washed three times with TBS-Tween-20 $(0.1 \%$ Tween-20) for $10 \mathrm{~min}$ each time. After $45 \mathrm{~min}$ of incubation with anti-mouse IgG and anti-rabbit IgG secondary antibodies (1:2,000; cat. nos. 7076 and 7074; CST Biological Reagents Co., Ltd.) at room temperature, the washing procedure was repeated. Protein expression was visualized using an enhanced chemiluminescent reagent (Beyotime Institute of Biotechnology) with Image J software (version 1.51k; National Institutes of Health, Bethesda, MD, USA), and the membrane was exposed to an X-ray film. Protein levels were detected in blots according to $\beta$-actin or lamin $\mathrm{B}$.

ELISA. BV2 cells were plated in 6-well plates ( $1 \times 10^{6}$ cells/well) and cultured in a cell culture box for $12 \mathrm{~h}$ until the cells completely attached to the wall. Subsequently, cells were treated with various concentrations of osthole $(4,7$ and $10 \mu \mathrm{g} / \mathrm{ml}$ ) for $1 \mathrm{~h}(5)$, followed by stimulation with LPS $(1 \mu \mathrm{g} / \mathrm{ml})$ for $6 \mathrm{~h}$. ELISA was performed on cell culture medium to determine the levels of tumor necrosis factor (TNF)- $\alpha$ (cat. no. EK0527), interleukin (IL)-6 (cat. no. EK0411) and IL-1 $\beta$ (cat. no. EK0394), according to the manufacturer's instructions (Boster Biological Technology Co., Ltd.). Absorbance was determined at $450 \mathrm{~nm}$.

Statistical analysis. Statistical analysis was performed with SPSS 17.0 (SPSS Inc., Chicago, IL, USA) with one-way analysis of variance. Data are presented as the mean \pm standard deviation of five independent experiments. Statistically significant differences were detected with one-way analysis of 
variance followed by Dunnet's test. $\mathrm{P}<0.05$ was considered to indicate a statistically significant difference.

\section{Results}

Effects of osthole on the viability of BV2 cells. The results of the MTT assay, which was used to detect the cell viability following incubation with LPS and/or osthole for $24 \mathrm{~h}$, are presented in Fig. 1. The results demonstrated that the addition of various concentrations of osthole $(4,7$ and $10 \mu \mathrm{g} / \mathrm{ml})$ to cells exhibited no cytotoxic effect, compared with the control group. Therefore, these three concentrations were selected for subsequent experiments.

Effects of osthole on inflammation-associated cytokines. To confirm the anti-inflammatory effects of osthole, the present study assessed cytokine production by BV2 cells using ELISA. The results demonstrated that the production of the inflammatory mediators IL-6, TNF- $\alpha$ and IL- $1 \beta$ in the cells following LPS stimulation was significantly increased, compared with the control group (Fig. 2). However, the LPS-induced increases in IL-6, TNF- $\alpha$ and IL- $1 \beta$ levels were dose-dependently inhibited by treatment with osthole (Fig. 2).

Effects of osthole on the expression of $N F-\kappa B$ pathway-associated proteins. Members of the NF- $\mathrm{B}$ family of proteins are considered to be key factors in inflammation. To investigate the effects of osthole on $\mathrm{NF}-\kappa \mathrm{B}$ activation induced by LPS, the present study performed western blotting. As demonstrated in Fig. 3, following LPS treatment, BV2 cells exhibited increased inflammation, as the expression of $\mathrm{NF}-\kappa \mathrm{B}$ pathway-associated proteins, such as p-NF- $\mathrm{B}$ p 65 and p-IкB $\alpha$, were increased. However, osthole blocked LPS-induced NF- $\kappa \mathrm{B}$ activation in a dose-dependent manner (Fig. 3).

Effects of osthole on the protein expression of Nrf2 and HO-1. Previous studies have reported that Nrf2 is involved in the regulation of antioxidant responses and inflammation (21-24). Western blotting demonstrated that the protein expression of Nrf2 and HO-1, which lies downstream of Nrf2, was further upregulated in osthole-treated BV2 microglia, compared with cells exposed to LPS alone (Fig. 4). These results indicated that osthole may induce the activation of the Nrf2 pathway.

\section{Discussion}

With increasing research on traditional Chinese medicine and its effective components, an increasing number of traditional Chinese medicines have been recognized worldwide. Traditional Chinese medicine and its effective components are considered to be safe, reliable and inexpensive. The mechanism of emodin has been extensively researched, and osthole, as an emerging Chinese medicine, has been widely investigated in recent years. Hao et al (25) demonstrated that osthole exhibited a therapeutic effect on pulmonary fibrosis, while Chen et al (26) reported beneficial effects of osthole on cognitive impairment in animals, which may occur via the Nrf2 pathway. These results indicate that osthole may act on the nervous system. Other studies have demonstrated that osthole may also exhibit an active role in non-nervous system diseases.

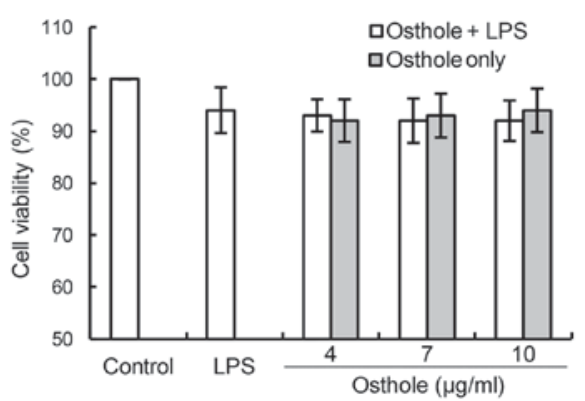

Figure 1. Effects of osthole on the viability of BV2 microglial cells. Cells were treated with osthole $(4,7$ and $10 \mu \mathrm{g} / \mathrm{ml})$ for $1 \mathrm{~h}$ and LPS $(1 \mu \mathrm{g} / \mathrm{ml})$ was subsequently added. Cell viability was determined at $24 \mathrm{~h}$ after the addition of LPS using an MTT assay. For groups treated with osthole, white bars indicate those treated with osthole + LPS and gray bars indicate those treated with osthole alone. Data are presented as the mean \pm standard error from five separate experiments. LPS, lipopolysaccharide.
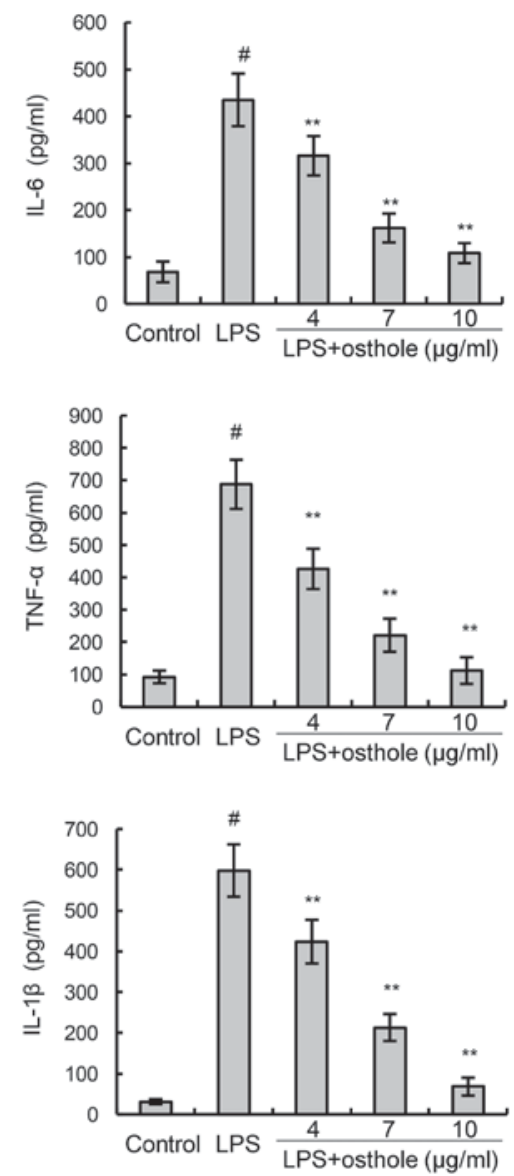

Figure 2. Effect of osthole on the production of inflammatory mediators by BV2 microglial cells. BV2 cells were pretreated with osthole $(4,7$ and $10 \mu \mathrm{g} / \mathrm{ml})$ for $1 \mathrm{~h}$, followed by stimulation with LPS $(1 \mu \mathrm{g} / \mathrm{ml})$ for $6 \mathrm{~h}$. TNF- $\alpha$, IL-1 $\beta$ and IL- 6 concentrations in the culture medium were assessed by ELISA. Data are presented as the mean \pm standard error from five separate experiments. ${ }^{*} \mathrm{P}<0.05$ vs. control group; ${ }^{* *} \mathrm{P}<0.01$ vs. LPS treatment group. LPS, lipopolysaccharide; TNF, tumor necrosis factor; IL, interleukin.

Osthole was previously reported to exhibit anti-inflammatory effects through $\mathrm{NF}-\kappa \mathrm{B}$ and mitogen-activated protein kinase signaling pathways (27). Furthermore, Liu et al (1) demonstrated the effect of osthole in mitochondrial disorders, 

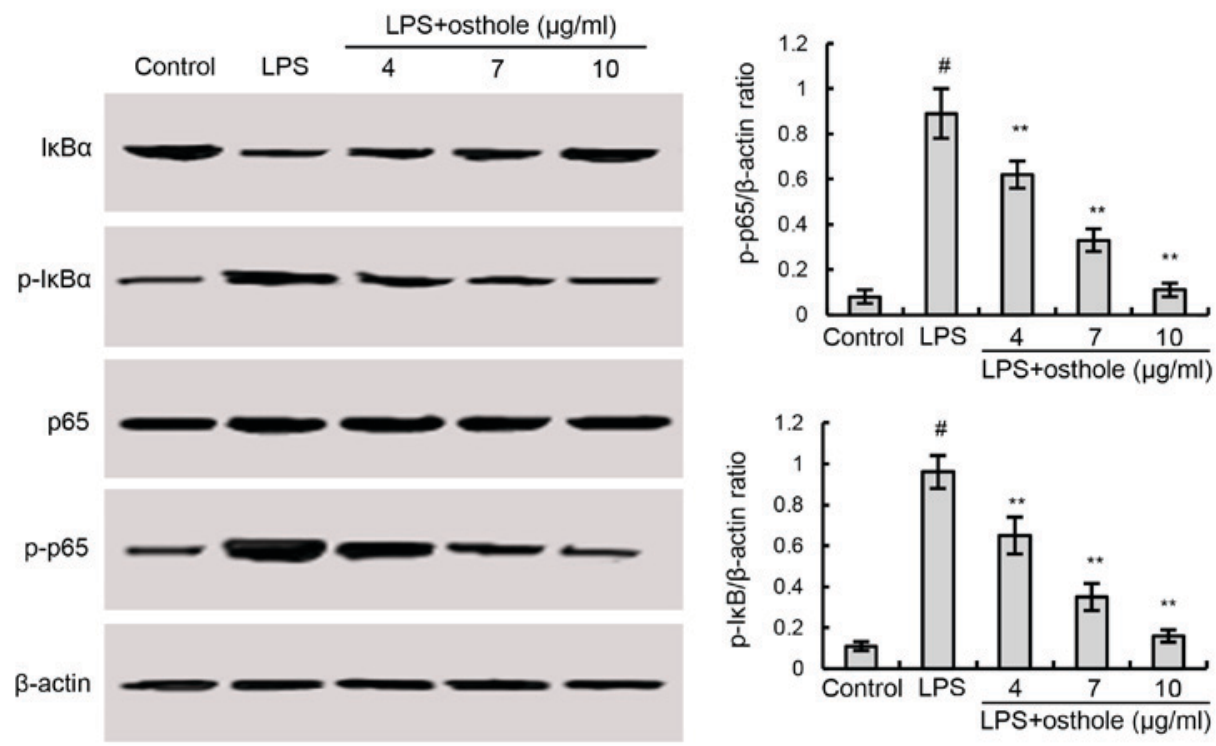

Figure 3. Effects of osthole and LPS on the protein expression of components of the NF-kB pathway in BV2 cells. BV2 cells were treated with osthole (4,7 and $10 \mu \mathrm{g} / \mathrm{ml})$ and LPS $(1 \mu \mathrm{g} / \mathrm{ml})$ for $24 \mathrm{~h}$. Western blotting was performed to determine the expression of proteins associated with the NF- $\kappa B$ pathway. Data are presented as the mean \pm standard error from five separate experiments. ${ }^{*} \mathrm{P}<0.05 \mathrm{vs}$. control group; ${ }^{* *} \mathrm{P}<0.01 \mathrm{vs}$. LPS treatment group. LPS, lipopolysaccharide;

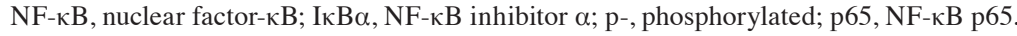
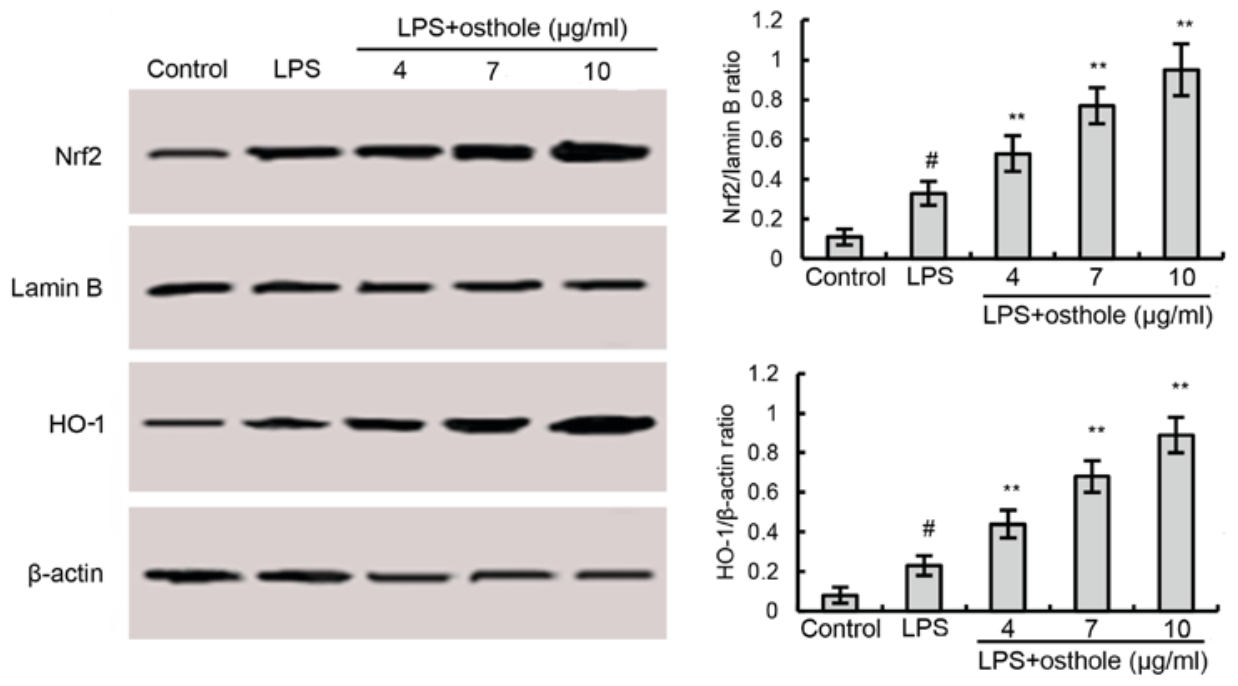

Figure 4. Effects of osthole and LPS on the protein expression of HO-1 and Nrf2. BV2 cells were treated with osthole $(4,7 \mathrm{and} 10 \mu \mathrm{g} / \mathrm{ml})$ and LPS $(1 \mu \mathrm{g} / \mathrm{ml})$ for $24 \mathrm{~h}$. Western blotting was performed to determine the protein expression of HO-1 and Nrf2. Data are presented as the mean \pm standard error from five separate experiments. ${ }^{\#} \mathrm{P}<0.05$ vs. control group; ${ }^{* *} \mathrm{P}<0.01$ vs. LPS treatment group. LPS, lipopolysaccharide; HO-1, heme oxygenase-1; Nrf2, nuclear factor erythroid 2-related factor 2.

Wang et al (28) reported that osthole inhibited inflammatory cytokine release in adipocytes, Huang and Dong (29) indicated that osthole exhibited anti-inflammatory effects in chronic kidney failure though the NF- $\mathrm{KB}$ pathway, and Hao and Liu (30) concluded that osthole reduced inflammatory responses in rats with pulmonary fibrosis. Although previous reports have investigated the role of osthole in the process of inflammation, the present study focused on inflammation in neurodegenerative diseases by using BV2 microglial cells. In addition to investigating conventional inflammatory factors, the present study also investigated the activation of the NF- $\mathrm{KB}$ and Nrf2 signaling pathways following osthole treatment. According to the results of western blotting and ELISA, osthole reduced the expression of proteins associated with NF- $\kappa \mathrm{B}$ and Nrf2 pathways. These results highlight the potential medicinal value of Fructus cnidii, which is another term for the traditional Chinese herb She Chuang Zi. With the discovery of the mechanism of action of this traditional Chinese medicine, osthole may have potential as an anti-inflammatory drug option.

Inflammation is a common pathological phenomenon that occurs in various disease states (31). BV2 cells are a type of mouse microglial cell, which are present in the brain and spinal cord (32). They are considered to be the first and most important line of defense in the central nervous system. A number of studies have demonstrated that macrophages 
stimulated by external antigens, such as LPS, release IL-1 $\beta$, TNF- $\alpha$ and other important inflammatory factors (33-37). These inflammatory cytokines promote an inflammatory reaction and lead to tissue damage. The results of the present study also demonstrated that stimulation of BV2 cells with LPS also led to the production of inflammatory factors, including TNF- $\alpha$, IL-6 and IL-1 $\beta$. It was also observed in the present study that the traditional Chinese medicine osthole affected this process and reduced the inflammatory response of BV2 cells following LPS stimulation.

In conclusion, the results of the present study demonstrated that osthole may protect inflammatory BV2 cells against inflammation induced by LPS stimulation, and this may occur through inhibition of the $\mathrm{NF}-\kappa \mathrm{B}$ and $\mathrm{Nrf} 2$ signaling pathways. However, a previous report by Chen et al (38) indicated that osthole was not able to inhibit the Nrf2 pathway. As a result, it may be concluded that, in the present study, the alterations in the expression of proteins associated with the Nrf2 pathway may occur as a result of the anti-inflammatory effects of osthole; it was previously reported that LPS induced Nrf2 and HO-1 activation (39). In the present study, osthole also reduced the release of inflammatory factors such as IL-1 $\beta$ and TNF- $\alpha$. These results may provide the scientific foundation for the effect of osthole in the prevention of nerve inflammation. Therefore, further investigation of this traditional Chinese is required to determine whether it may be employed for the treatment of various types of inflammation in the future.

\section{References}

1. Liu WB, Zhou J, Qu Y, Li X, Lu CT, Xie KL, Sun XL and Fei Z: Neuroprotective effect of osthole on $\mathrm{MPP}^{+}$-induced cytotoxicity in PC12 cells via inhibition of mitochondrial dysfunction and ROS production. Neurochem Int 57: 206-215, 2010.

2. Ogawa H, Sasai N, Kamisako T and Baba K: Effects of osthol on blood pressure and lipid metabolism in stroke-prone spontaneously hypertensive rats. J Ethnopharmacol 112: 26-31, 2007.

3. Zhou F, Zhong W, Xue J, Gu ZL and Xie ML: Reduction of rat cardiac hypertrophy by osthol is related to regulation of cardiac oxidative stress and lipid metabolism. Lipids 47: 987-994, 2012.

4. Liu J, Xu R and Zhao X: Mechanisms for effect of osthole on inhibiting the growth and invasion of bladder cancer cells. Zhong Nan Da Xue Xue Bao Yi Xue Ban 41: 345-352, 2016 (In Chinese).

5. Pan Z, Fang Z, Lu W, Liu X and Zhang Y: Osthole, a coumadin analog from Cnidium monnieri (L.) Cusson, stimulates corticosterone secretion by increasing steroidogenic enzyme expression in mouse Y1 adrenocortical tumor cells. J Ethnopharmacol 175: 456-462, 2015.

6. Chun J, Tosun A and Kim YS: Anti-inflammatory effect of corymbocoumarin from Seseli gummiferum subsp. corymbosum through suppression of NF- $\mathrm{KB}$ signaling pathway and induction of HO-1 expression in LPS-stimulated RAW 264.7 cells. Int Immunopharmacol 31: 207-215, 2016.

7. Menden HL, Xia S, Mabry SM, Navarro A, Nyp MF and Sampath V: Nicotinamide adenine dinucleotide phosphate oxidase 2 regulates LPS-induced inflammation and alveolar remodeling in the developing lung. Am J Respir Cell Mol Biol 55: 767-778, 2016.

8. Bozic I, Savic S, Laketa D, Bjelobaba I, Milenkovic I, Pekovic S, Nedeljkovic $\mathrm{N}$ and Lavrnja I: Benfotiamine attenuates inflammatory response in LPS stimulated BV-2 microglia, PLoS One 10: $\mathrm{e} 0118372,2015$.

9. Yang L, Guo H, Jin X, Meng X, Yan L, Dan Z, Wu S, Zhou H, Peng L, Xie Q and Jin X: Oleoylethanolamide exerts anti-inflammatory effects on LPS-induced THP-1 cells by enhancing PPAR $\alpha$ signaling and inhibiting the NF- $\mathrm{BB}$ and ERK1/2/AP-1/STAT3 pathways. Sci Rep 6: 34611, 2016.
10. Shi J, Shan S, Li H, Song G and Li Z: Anti-inflammatory effects of millet bran derived-bound polyphenols in LPS-induced HT-29 cell via ROS/miR-149/Akt/NF- $\kappa$ B signaling pathway. Oncotarget 8: 74582-74594, 2017.

11. Fan C, Wu L, Zhang G, Xu F, Zhang S, Zhang X, Sun L, Yu Y, Zhang Y and Ye RD: 4'-Hydroxywogonin suppresses lipopolysaccharide-induced inflammatory responses in RAW 264.7 macrophages and acute lung injury mice. PLoS One 12: e0181191, 2017.

12. Minagar A, Shapshak P, Fujimura R, Ownby R, Heyes M and Eisdorfer C: The role of macrophage/microglia and astrocytes in the pathogenesis of three neurologic disorders: HIV-associated dementia, Alzheimer disease, and multiple sclerosis. J Neurol Sci 202: 13-23, 2002.

13. Gasparini C, Celeghini C, Monasta L and Zauli G: NF-kappaB pathways in hematological malignancies. Cell Mol Life Sci 71: 2083-2102, 2014

14. Shih RH, Wang CY and Yang CM: NF-kappaB signaling pathways in neurological inflammation: A mini review. Front Mol Neurosci 8: 77, 2015.

15. Brambilla R, Bracchi-Ricard V, Hu WH, Frydel B, Bramwell A, Karmally S, Green EJ and Bethea JR: Inhibition of astroglial nuclear factor kappaB reduces inflammation and improves functional recovery after spinal cord injury. J Exp Med 202: 145-156, 2005.

16. Noort AR, Tak PP and Tas SW: Non-canonical NF- $\kappa B$ signaling in rheumatoid arthritis: Dr Jekyll and Mr Hyde? Arthritis Res Ther 17: 15, 2015.

17. Duh EJ, Maury WJ, Folks TM, Fauci AS and Rabson AB: Tumor necrosis factor alpha activates human immunodeficiency virus type 1 through induction of nuclear factor binding to the NF-kappa B sites in the long terminal repeat. Proc Natl Acad Sci USA 86: 5974-5978, 1989.

18. Khodir AE, Atef H, Said E, ElKashef HA and Salem HA: Implication of Nrf2/HO-1 pathway in the coloprotective effect of coenzyme Q10 against experimentally induced ulcerative colitis. Inflammopharmacology 25: 119-135, 2017.

19. Cao S, Du J and Hei Q: Lycium barbarum polysaccharide protects against neurotoxicity via the Nrf2-HO-1 pathway. Exp Ther Med 14: 4919-4927, 2017.

20. Kwon YW, Cheon SY, Park SY, Song J and Lee JH: Tryptanthrin suppresses the activation of the LPS-treated BV2 microglial cell line via Nrf2/HO-1 antioxidant signaling. Front Cell Neurosci 11: 18, 2017.

21. Bachewal P, Gundu C, Yerra VG, Kalvala AK, Areti A and Kumar A: Morin exerts neuroprotection via attenuation of ROS induced oxidative damage and neuroinflammation in experimental diabetic neuropathy. Biofactors: Nov 28, 2017 (Epub ahead of print).

22. Truong VL, Jun M and Jeong WS: Role of resveratrol in regulation of cellular defense systems against oxidative stress. Biofactors: Nov 28, 2017 (Epub ahead of print).

23. Chen QM and Maltagliati AJ: Nrf2 at the heart of oxidative stress and cardiac protection. Physiol Genomics: Nov 29, 2017 (Epub ahead of print).

24. Aldaba-Muruato LR, Muñoz-Ortega MH, Macías-Pérez JR, Pulido-Ortega J, Martínez-Hernández SL and Ventura-Juárez J: Adrenergic regulation during acute hepatic infection with Entamoeba histolytica in the hamster: Involvement of oxidative stress, Nrf2 and NF-KappaB. Parasite 24: 46, 2017.

25. Hao Y and Liu Y: Osthole alleviates bleomycin-induced pulmonary fibrosis via modulating angiotensin-converting enzyme 2/angiotensin-(1-7) axis and decreasing inflammation responses in rats. Biol Pharm Bull 39: 457-465, 2016.

26. Chen Z, Mao X, Liu A, Gao X, Chen X, Ye M, Ye J, Liu $\mathrm{P}$, Xu S, Liu J, et al: Osthole, a natural coumarin improves cognitive impairments and $\mathrm{BBB}$ dysfunction after transient global brain ischemia in C57 BL/6J mice: Involvement of Nrf2 pathway. Neurochem Res 40: 186-194, 2015.

27. Wu SJ: Osthole attenuates inflammatory responses and regulates the expression of inflammatory mediators in HepG2 cells grown in differentiated medium from 3T3-L1 preadipocytes. J Med Food 18: 972-979, 2015.

28. Wang XL, Shang X, Cui Y, Zhao X, Zhang Y and Xie ML: Osthole inhibits inflammatory cytokine release through PPAR $\alpha /$ $\gamma$-mediated mechanisms in LPS-stimulated 3T3-L1 adipocytes. Immunopharmacol Immunotoxicol 37: 185-192, 2015. 
29. Huang $\mathrm{T}$ and Dong Z: Osthole protects against inflammation in a rat model of chronic kidney failure via suppression of nuclear factor- $\kappa \mathrm{B}$, transforming growth factor- $\beta 1$ and activation of phosphoinositide 3-kinase/protein kinase B/nuclear factor (erythroid-derived 2)-like 2 signaling. Mol Med Rep 16: 4915-4921, 2017.

30. Hao Y and Liu Y: Osthole alleviates bleomycin-induced pulmonary fibrosis via modulating angiotensin-converting enzyme 2/angiotensin-(1-7) axis and decreasing inflammation responses in rats. Biol Pharm Bull 39: 457-465, 2016.

31. Lee HH, Shin JS, Lee WS, Ryu B, Jang DS and Lee KT: Biflorin, isolated from the flower buds of syzygium aromaticum L., suppresses LPS-induced inflammatory mediators via STAT1 inactivation in macrophages and protects mice from endotoxin shock. J Nat Prod 79: 711-720, 2016.

32. Cho N, Moon EH, Kim HW, Hong J, Beutler JA and Sung SH: Inhibition of nitric oxide production in BV2 microglial cells by triterpenes from tetrapanax papyriferus. Molecules 21: 459, 2016

33. Sun Y and Shang D: Inhibitory effects of antimicrobial peptides on lipopolysaccharide-induced inflammation. Mediators Inflamm 2015: 167572, 2015.

34. Tai Y, Qiu Y and Bao Z: Magnesium lithospermate B suppresses lipopolysaccharide-induced neuroinflammation in BV2 microglial cells and attenuates neurodegeneration in lipopolysaccharide-injected mice. J Mol Neurosci: Dec 1, 2017 (Epub ahead of print).
35. He Y, She H, Zhang T, Xu H, Cheng L, Yepes M, Zhao Y and Mao Z: p38 MAPK inhibits autophagy and promotes microglial inflammatory responses by phosphorylating ULK1. J Cell Biol: Dec 1, 2017 (Epub ahead of print).

36. Xu L, Zheng X, Wang Y, Fan Q, Zhang M, Li R, Ye J, Wu X, Zhao $\mathrm{W}$ and Zhang Y: Berberine protects acute liver failure in mice through inhibiting inflammation and mitochondria-dependent apoptosis. Eur J Pharmacol 819: 161-168, 2017.

37. Wang S, Zhang Z, Wang Y, Gadahi JA, Xie Q, Xu L, Yan R, Song $\mathrm{X}$ and Li X: Toxoplasma gondii excretory/secretory antigens (TgESAs) suppress pro-inflammatory cytokine secretion by inhibiting TLR-induced NF- $\kappa$ B activation in LPS-stimulated murine macrophages. Oncotarget 8: 88351-88359, 2017.

38. Chen XJ, Zhang B, Hou SJ, Shi Y, Xu DQ, Wang YX, Liu ML, Dong HY, Sun RH, Bao ND, Jin FG and Li ZC: Osthole improves acute lung injury in mice by up-regulating Nrf-2/thioredoxin 1. Respir Physiol Neurobiol 188: 214-222, 2013.

39. Tursun X, Zhao Y, Alat Z, Xin X, Tursun A, Abdulla R and AkberAisa $\mathrm{H}$ : Anti-inflammatory effect of rosa rugosa flower extract in lipopolysaccharide-stimulated RAW264.7 macrophages. Biomol Ther (Seoul) 24: 184-190, 2016. 